\title{
SELECTED PROBLEMS OF ADDITIVE MANUFACTURING USING SLS/SLM PROCESSES
}

\author{
Jerzy Kozak ${ }^{1}$ (i) 0000-0002-4232-4498, \\ Tomasz Zakrzewski ${ }^{2}$ iD 0000-0002-0502-5034, \\ Marta Witt ${ }^{1}$ (D) 0000-0003-3093-9548, \\ Martyna Dębowska-Wąsak ${ }^{1}$ (D) 0000-0001-6761-9121. \\ ${ }^{1}$ Łukasiewicz Research Network - Institute of Aviation, Al. Krakowska 110/114, Warsaw 02-256, Poland \\ ${ }^{2}$ General Electric, Al. Krakowska 110/114, Warsaw 02-256, Poland \\ jerzy.kozak@ilot.lukasiewicz.gov.pl \\ tomz@wp.pl \\ marta.witt@ilot.lukasiewicz.gov.pl \\ martyna.debowska@ilot.lukasiewicz.gov.pl
}

\begin{abstract}
Additive Manufacturing (AM) based on Selective Laser Sintering (SLS) and Selective Laser Melting (SLM) is relatively widely used to manufacture complex shape parts made from metallic alloys, ceramic and polymers. Although the SLM process has many advantages over the conventional machining, main disadvantages are the relatively poor surface quality and the occurrence of the material structure defect porosity.

The paper presents key problems directly related to the implementation of AM, and in particular the selection and optimization of process conditions. The first section examines the issues of dimensional accuracy, the second surface quality and porosity problem determining the mechanical properties of manufactured products.
\end{abstract}

Keywords: additive manufacturing, metal 3D printing, SLS/SLM processes.

Type of the work: Research Paper

\section{NOMENCLATURE}

$\begin{array}{llll}P & \text { Laser beam power }[\mathrm{W}] & c v & \text { Specific Heat }[\mathrm{J} / \mathrm{kgK}] \\ V & \text { Laser scanning speed }[\mathrm{mm} / \mathrm{s}] & T m & \text { Melting temperature }[\mathrm{K}] \\ P d & \text { Hatch spacing }[\mu \mathrm{m}] & d & \text { Laser spot diameter }[\mu \mathrm{m}] \\ h & \text { Powder bed thickness }[\mu \mathrm{m}] & \beta & \text { Porosity }[\%] \\ R a & \text { Surface Roughness }(\text { Average })[\mu \mathrm{m}] & \rho & \text { Specimen density }[\mathrm{g} / \mathrm{cm} 3] \\ \mathrm{Lm} & \text { Heat Latent of fusion }[\mathrm{J} / \mathrm{kg}] & \pi i & \text { Dimensionless parameter }[-]\end{array}$




\section{INTRODUCTION}

The long term strategic objectives "Flightpath 2050"have taken the Advisory Council for Aviation Research in Europe (ACARE) development targets beyond the year 2020. By year 2050, the following goals for air traffic have to be achieved [1]:

- $\quad 75 \%$ reduction in $\mathrm{CO}_{2}$ per passenger kilometer;

- $\quad 90 \%$ reduction in NOx emissions;

- $\quad 65 \%$ reduction in noise.

Above improvements require changes in aircraft engines design. The further development of turbine engines is decreasing unitary fuel consumption, device weight, exploitation costs and negative effects on natural environment.

Achievement of these goals significantly depends on the introduction of new manufacturing techniques, in particular on the use of Additive Manufacturing.

Additive Manufacturing (AM), Layered Manufacturing (LM), or Solid Freeform Fabrication (SFF) is a class of manufacturing methods that has seen a rapid growth over the years since inception in late 80 's [2-6].

Additive manufacturing (AM) processes make a three-dimensional (3D) product by gradually adding thin layers of materials controlled by a digital model.

As opposed to conventional manufacturing processes (involving material removal to achieve final shape), the layered manufacturing is an additive process wherein the part is built by sequentially fusing thin layers of material one over another. Due to additive build-up principle it has an inherent advantage of producing parts of unlimited geometrical complexity offering possibilities for optimization even by geometrical means.

The geometric freedom enables the designer to realize lightweight, complex hollow structures, overhangs and lattice structures, which are being used particularly in aerospace industry.

The process uses sliced CAD data to generate successive layers from bottom to top resulting in the final product (Fig. 1).

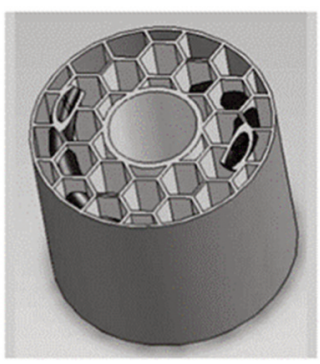

(a) CAD file

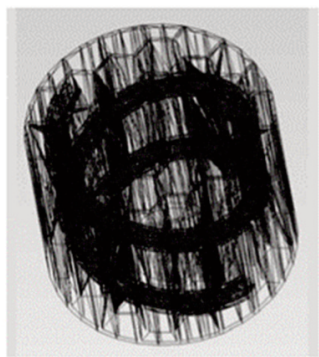

(b) STL file

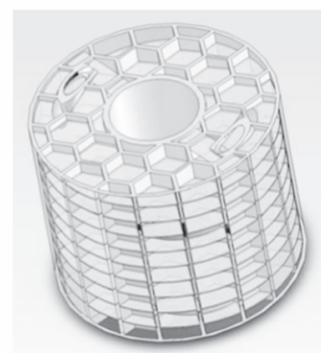

(c) sliced STL file

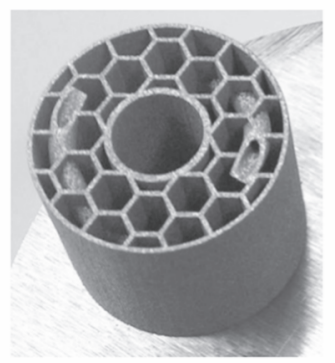

(d) Final part

Fig. 1. Additive Manufacturing process steps [4].

Layered manufacturing enables quick production of complex three-dimensional parts of designed macro and microstructure directly from CAD data, almost entirely eliminating the intermediate tooling steps, therefore shortening production time and reducing associated costs. Another significant advantage associated with LM technique is that the cost and production time do not increase with the degree of complexity.

Most current metal additive manufacturing systems are of the powder bed fusion type. In the powder bed fusion process, thin layers of powder are applied to a build plate and an energy source (a laser or electron beam) is used to fuse the powder at locations specified by the model of desired geometry. 
When one layer is completed, a new layer of powder is applied and the process is repeated until a 3D part is produced. The powder bed fusion process is alternately known as selective laser sintering (SLS), selective laser melting (SLM), direct metal laser sintering (DMLS), direct metal laser melting (DMLM), and electron beam melting (EBM).

Selective Laser Melting (SLM) is one of the most versatile advanced in additive manufacturing and is a factor qualifying the rapid manufacturing as the most innovative and potentially disruptive manufacturing technology [1-5]. One of SLM's main features is that it can be applied to a wide range of materials (metals, ceramics, composites).

Schematic diagram of SLS/SLM process is shown in (Fig. 2).

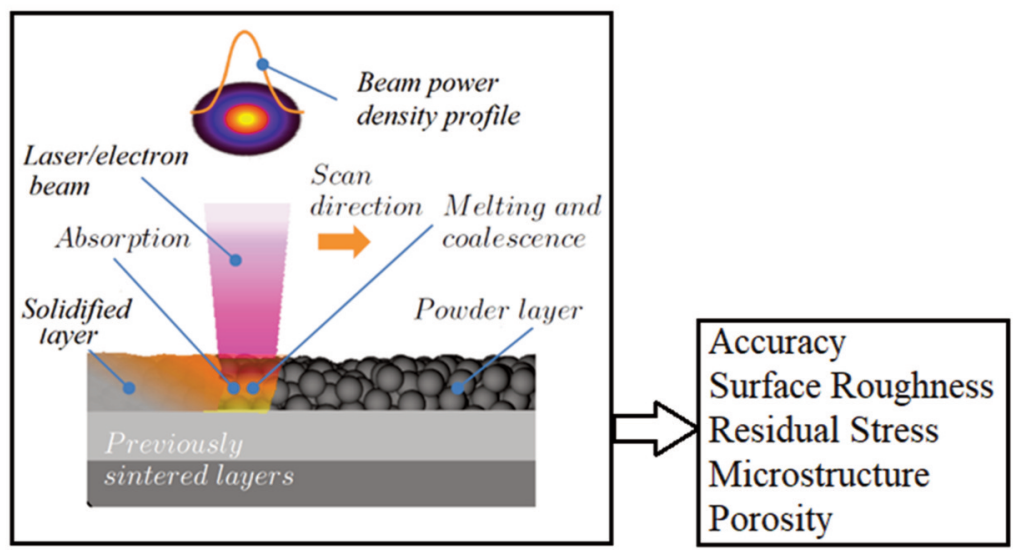

Fig. 2. Schematic of laser sintering/melting showing key phenomena and effects occurring during the SLS/ SLM processes.

One of the biggest adopters of AM (and SLS/SLM in particular) has been the aerospace industry. In addition to using AM for rapid prototyping of design changes, entire parts are now fabricated using SLS/SLM, which have the benefits of being lighter, cheaper and quicker to manufacture.

According to the National Center for Manufacturing Science, AM can reduce the production time by $40 \%$. SLS/SLM has also shown the capability of producing hard metal parts such as tungsten carbidecobalt (WC-Co) and titanium carbide-nickel (TiC-Ni) used in machining tools and abrasion resistant coatings. Examples of fabricated parts are shown in Fig. 3.
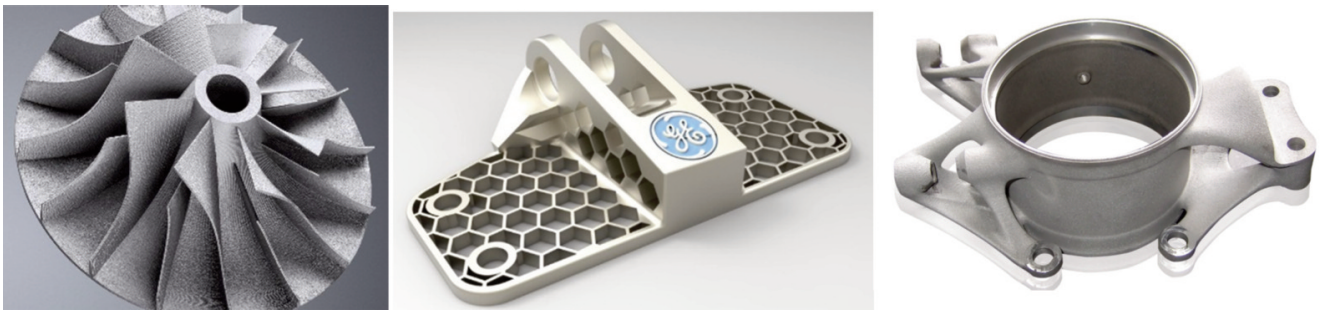

Fig. 3. Example of parts fabricated by SLM process [6].

SLM process is based on many physical phenomena such as a laser energy absorption, radiation, heat transfer in solid and liquid phase, phase transformation, evaporation, convection, gradient of surface tension in molten powder pool causing fluid flow and chemical reactions. 
Many process parameters have significant impact on tracks formation. Most of them influence on energy density level acting to powder bed: laser power, scanning speed, hatch distance, powder layer thickness, scanning strategy (Fig. 4). Atmosphere in machine chamber as well as powder initial temperature may also result in final solidified track shape.
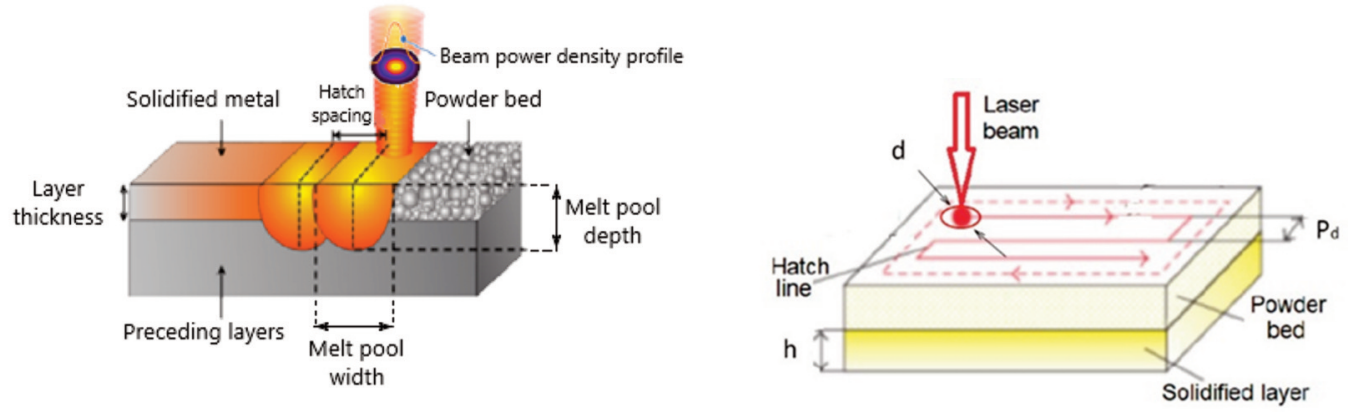

Fig. 4. Track formation scheme [adopted from 5 and 16].

Although the SLM process has many advantages over the conventional machining, main disadvantages are the relatively low accuracy, poor surface quality and the occurrence of the material structure defect porosity.

The paper presents key problems directly related to the implementation of AM, and in particular the selection and optimization of process conditions. The first section examines the issues of dimensional accuracy, the second surface quality and the porosity, that determines the mechanical properties of manufactured products.

\section{THE SLS/SLM ACCURACY PROBLEMS}

There are several factors in the SLS/SLM process which may have an influence on the dimensional accuracy [7]:

- Part geometry;

- $\quad$ Powder composition, powder size, reuse powder process;

- Machine tool specification, characteristics of optic-mechanical systems of machine and work chamber: build atmosphere, purge gas, airflow, preheat temperature;

- $\quad$ Laser power, laser spot diameter and mode of radiation;

- $\quad$ Scan speed (travel speed, dwell time);

- $\quad$ Hatch strategy: contour pass line spacing and boundary overlap;

- $\quad$ Layer thickness;

- $\quad$ Part orientation on machine build platform (machine working space);

- $\quad$ Shrinkage and residual thermal stresses in solidified part.

In general, the influence factors can be divided into six groups: geometric, material, measurement, machine-specific, environmental and procedural. Both powder layer thickness and the Stereolithography (STL) file quality have an impact on geometrical deviation between printed part and 3D model. STL file is generated based on CAD model through triangular approximation. In all cases chordal deviation between 3D model and STL facet can be observed but it can be mitigated by 3D model quality improvement. Geometrical deviation known as "staircase effect" is related to powder layer thickness and 
appears on built parts' side walls. Side wall surface resolution is determined by the layer thickness. Thinner layers used in build process result in better surface integrity, but it extends manufacturing time. Typical layer thickness used in process is in range from $20 \mu \mathrm{m}$ and $60 \mu \mathrm{m}$.

Moreover, machine errors, process parameter settings and material shrinkage will also bring about deviations that affect the geometric consistency between nominal model and final product. After the process, the sintered part shrinks as it cools. To compensate the effect of material shrinkage, the 2D-layer model needs to be scaled first. Besides these, an offset of the $2 \mathrm{D}$-model is processed to compensate the effect of finite diameter of the laser beam spot. Effective modeling and control of these deviations is obviously critical for an optimal design for AM.

Unfortunately, their mutual interaction is not always clear. That is why scientific understanding of the process parameters modification is very important, i.e. how the modification of each of these parameters influences on the other and the SLM process as a whole. Let us consider the dimensional errors arising from the multilayer material processing.

Let us consider the height of the manufactured product $H_{n}$, which can be written as:

$$
H_{n}=\sum_{i=1}^{n} h_{s i}
$$

where $h_{s i}$ is the thickness of the single solidified layer (Fig. 6).

Therefore resultative error of the part's height is:

$$
\Delta H_{n}=\sum_{i=1}^{n} \Delta h_{s i}
$$

where $\Delta h_{\mathrm{si}}$ is deviation/error of single solidified layer thickness $h_{s i}$.

Its standard deviation $s_{H}$ is described as:

$$
S_{H}=\sqrt{\sum_{i=1}^{n} s_{s i}^{2}}
$$

where $s_{s i}$ are standard deviations of the single solidified layer.

At assumption of uniform average thickness solidified layer equal of average value $h_{L}$ and its average standard deviation $s_{b}$, the final dimension of the part height is equal:

$$
H_{n}=n \cdot h_{L}
$$

and standard deviation:

$$
s_{H}=s_{h} \sqrt{n}
$$

Since SLM is a layer-by-layer technique, the solidified layer thickness is one of the determinant factors of this process. 


\section{The one-dimensional (1-D) thermal model}

For estimation of effect process parameters on the thickness of solidified layer, a simple mathematical model of SLM has been developed. During laser heating, laser energy heats up the powder solid substrate from chamber preheating temperature to the melting point. To determine the temperature profile in the powder bed and the time required to initiate melting, the one-dimensional transient heat conduction in a semi-infinite solid has been generally applied to the process estimation. Consider a solid plate subjected to a laser heat beam at the surface $(z=0)$ as illustrated in Fig. 5.

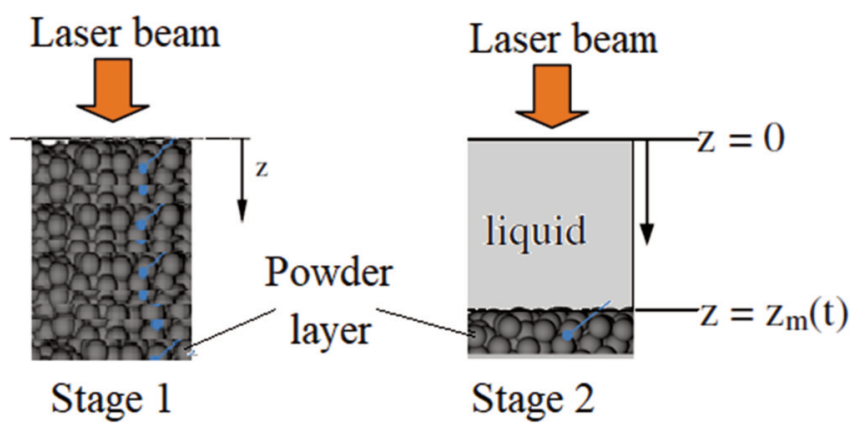

Fig. 5. Schematic diagram of stage 1: powder heating.

\section{Stage 1: powder heating.}

The heat conduction equation can be written as:

$$
\frac{\partial T_{p}}{\partial t}=a_{e f} \frac{\partial^{2} T_{p}}{\partial z^{2}}
$$

where $T_{p}, t, z$ and $a_{e f}$ are the temperature in the powder layer, time, vertical distance, and effective thermal diffusivity of the powder layer, respectively.

The boundary and initial conditions are:

$$
\begin{aligned}
& T_{p}(z, 0)=T_{0} \\
& \mid-k_{e f}{\frac{\partial T_{p}}{\partial z_{z=0}}=q_{p}}
\end{aligned}
$$

where $k_{e f}$ is the effective thermal conductivity of the powder layer, $T_{0}$ is the powder temperature after preheating, and $q_{p}$ is absorbed laser intensity defined by:

$$
q_{p}=\eta I_{0}
$$

where $I_{0}, \eta$ are the incident laser power density and absorptivity of the powder, respectively. 
The laser power density is equal:

$$
I_{0}=\frac{4 P}{\pi d^{2}}
$$

where $P$ is laser power and $d$ spot diameter.

Carslaw and Jaeger [8] assumed that there would be solutions to the above system of equations if the laser absorption profile was in the form:

$$
q(z, t)=q_{P} \operatorname{erf} c \frac{z}{2 \sqrt{a_{P} t}}
$$

where $\operatorname{erf} c$ is the complimentary error function and is defined by:

$$
\operatorname{erfc}(z)=1-\operatorname{erfc}(z)=\frac{2}{2 \sqrt{\pi}} \int_{z}^{\infty} e^{-u^{2}} d u
$$

where $u$ is a temporal variable defined here for integrating.

The temperature profile in solid is then found to be:

$$
T_{p}(z, t)=T_{0}+\frac{2 q_{p}}{k_{e f}}\left[\left(\frac{a_{e f} t}{\pi}\right)^{1 / 2} e^{-z^{2} / 4 a_{e f} t}-\frac{z}{2} \operatorname{erfc} \frac{z}{2 \sqrt{a_{e f} t}}\right]
$$

It is important to determine the temperature at the surface so that the time required to initiate the melting can be estimated. According to Eq. 13, for a single laser pulse heating, the temperature at the surface $(z=0)$ can now be determined from $[8,9]$ :

$$
T_{p}(0, t)=T_{0}+\frac{2 q_{p}}{k_{e f}}\left(\frac{a_{e f} t}{\pi}\right)^{1 / 2}
$$

\section{Stage 2: melting.}

If energy of the laser beam incident on the solid surface is sufficient, melting begins and the solidliquid interface is formed and propagates into the solid. Analysis of melting can be described as the Stefan problem which deals with the phase change process with moving boundary [5, 8, 9]. Extensive works have been carried out to study the laser induced melting of material, including analytical model sand numerical simulations. Consider a plate irradiated with the laser beam at the surface where a thin layer of molten liquid is formed, as shown in Fig. 5. Because the melt pool diameter is much larger than the melt thickness, and because the melting occurs dominantly in the vertical direction, a one-dimensional approach may be assumed.

Heat conduction equations in the liquid and solid can be described as $[8,9]$ :

$$
\begin{array}{ll}
\frac{\partial T_{l}}{\partial t}=a_{l} \frac{\partial^{2} T_{l}}{\partial z^{2}} ; & 0<z \leq z_{m} \\
\frac{\partial T_{P}}{\partial t}=a_{e f} \frac{\partial^{2} T_{P}}{\partial z^{2}} ; & z_{m}<z \leq \infty
\end{array}
$$


with boundary and initial conditions:

$$
\begin{array}{ll}
-k_{e f} \frac{\partial T_{p}(z, t)}{\partial z}=q_{p} ; & z=0 \\
T_{p}(z, t)=T_{l}(z, t)=T_{m} ; & z=z_{m}(t) \\
\rho_{p} L_{m} \frac{d z_{m}(t)}{d t}=k_{e f} \frac{\partial T_{p}(, t)}{\partial z}-k l \frac{\partial T_{l}(z, t)}{\partial z} ; & z=z_{m}(t) \\
T_{p}(0, t)=T_{0} ; & z \rightarrow \infty \\
z_{m}\left(t_{m}\right)=0 ; & t=t_{m}
\end{array}
$$

where $T_{l}(z, t)$ and $T_{p}(z, t)$ are the temperature profiles in liquid and solid, $k_{e f} \rho_{p}$ and $\mathrm{a}_{1}$ are the thermal conductivity, density, and thermal diffusivity of the liquid, $L_{m}, t_{m}$, and $z_{m}(t)$ are the latent heat of melting, the time required to initiate melting, and the melting front location, respectively.

To date, solutions to the above set of nonlinear partial differential equations have been proposed by several authors. Based in this case on the solution given in ref. [10], the front location of melting is described as follows:

$$
h_{L}(t)=\frac{0.64 \eta P\left(t-t_{m}\right)}{\pi d^{2} \rho_{m}(1-\beta) L_{m}}
$$

where the time to start melting, $t_{m}$, is given by:

$$
t_{m}=\frac{\pi^{3} T_{m}^{2} k_{e f}^{2} d^{4}}{64 a_{e f} \eta^{2} P^{2}}
$$

These expressions $(22,23)$ have been used in sensitivity analysis of SLS/SLM processes for estimation of the influence of process condition changes on thickness of solidified layer.

\section{Sensitivity analysis}

The powerful tool for this kind of study is the sensitivity analysis [11]. Its objective is to quantify how changes in the design parameters (design variables) affect the value of response. The design parameters can be categorized as follows:

- Geometrical process parameters $p_{i}^{g}$ (e.g. dimensions such as laser spot diameter);

- $\quad$ Powder parameters $p_{j}^{m}$ (e.g. $\left.L_{m}, \ldots\right)$;

- $\quad$ Fabrication design parameters $p_{k}^{f}$ (e.g. power density, pulse time on, pulse time off, laser scan speed).

The crucial step for the sensitivity analysis is the mathematical model of the device, which describes with sufficient accuracy (as it is assumed) the relation between value of response $R$ and values of design parameters $p_{i}^{g}, p_{j}^{m}, p_{k}^{f}$ :

$$
R=R\left(p_{i}^{g}, p_{j}^{m}, p_{k}^{f}\right)=R\left(p_{l}\right)
$$


The change of response function $R$ due to changes in the process parameters may be approximated via a first order Taylor series expansion:

$$
\Delta R \approx \sum_{l} \frac{\partial R}{\partial p_{l}} \cdot \Delta p_{l}
$$

In practice, usually the maximal relative change of response is used:

$$
\frac{\Delta R}{R} \approx 1 / R \sum_{l}\left|\frac{\partial R}{\partial p_{l}}\right| \cdot \Delta p_{l}
$$

The sensitivity coefficients $\frac{\partial R}{\partial p_{l}}$ can be determined analytically.

As a rule only, some of the design process parameters have significant influence on the relative change of the response. During the design process (mainly during synthesis) the engineers have to investigate several "what if" questions. The knowledge of sensitivity coefficients enables them to formulate not only qualitative, but what is more important, quantitative answers. Sometimes, when the statistical characteristics of design parameters (for example, mean values and standard deviations) are available, the statistical sensitivity analysis can be applied.

In such a case, the mean value of response $\bar{R}$ is determined as follows:

$$
\bar{R}=\bar{R}\left(\bar{p}_{l}\right)
$$

where $\bar{p}_{l}$ are mean values of design parameters. Its standard deviation $s_{R}$ is described as:

$$
s_{R}=\sqrt{\sum_{l}\left(\frac{\partial R}{\partial p_{l}}\right)^{2} \cdot s_{l}^{2}}
$$

where $s_{l}$ are standard deviations of independent process parameters.

In the case of analysis of SLS/SLM, the response function is as thickness of solicited layer $h_{L}$ described by (22 and 23). For purpose of this analysis, the quasi-homogenous material representing metallic powder bed has been assumed. This assumption has been considered as sufficient to determine temperature distribution in sample being under analysis. As first phase of thermal process is metallic powder heating up using laser beam. Depending on the metallic powder used (grain size, powder composition), the observed volume decreases due to air release from the powder. Powder is being molten and laser energy consumed for transformation from solid to liquid phase. Temperature stays constant during the powder transformation from solid particles to liquid phase. All energy is consumed to increase distance between atoms. Fig. 6 shows volume difference between powder volume and liquid and solid phases. However layer thickness $\mathrm{h}$ is considered as sufficient to determine thermal expansion for 1D model (29).

$$
h_{\text {solid }}=h_{\text {liquid }}(1-\gamma)
$$

where $\gamma$ is coefficient of thermal expansion. 


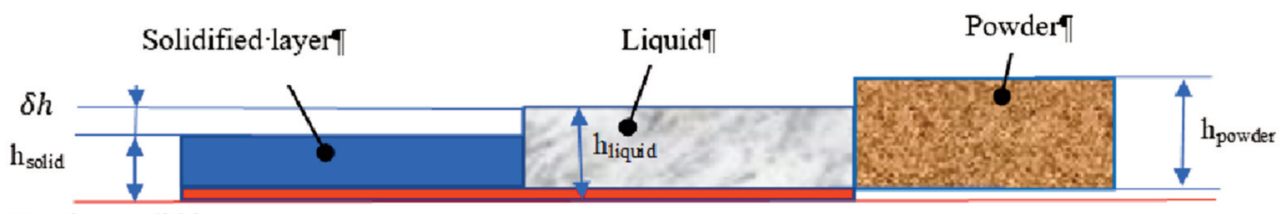

Previous solid layer

Fig. 6. One-dimensional (1D) shows melting process sequence starting from powder to solidified layer.

Moreover, the previous solid layer is being molten at the same time as the top layer of powder in being heated up and molten by laser beam. This condition is required for part quality and no powder existence in part internal structure. Molten layer depth depends on laser energy, time of exposure, powder density, previous created solid layer density and temperature $T_{0}$ (ambient temperature). Desired is to melt powder layer as well as previous created (melted) layer to have homogenous structure and to avoid not fully laser beam penetration.

\section{Experiment data and calculations}

The reference values have been determined for the same base setting parameters of experiments and calculations.

Selected data of powder used for analysis purpose is shown in (Tab. 1).

The material is widely used in aerospace industry as well as motorsports and medical applications.

Titanium alloys found their application mostly to build lightweight structures, prototypes, and human body implants.

Tab. 1. Powder type CL 41TI ELI Titanium alloy (TiAl64V ELI).

\begin{tabular}{lc}
\hline Powder Property & Value \\
\hline Thermal conductivity $k_{e f}$ & $7 \mathrm{~W} / \mathrm{mK}$ \\
Coefficient of thermal expansion $\gamma$ & $910^{-6} \mathrm{~K}^{-1}$ \\
Porosity $\beta$ & 0.15 \\
\hline
\end{tabular}

Performed analysis based on one dimensional model shown relation between molten powder thickness and laser beam irradiation (Fig. 7).

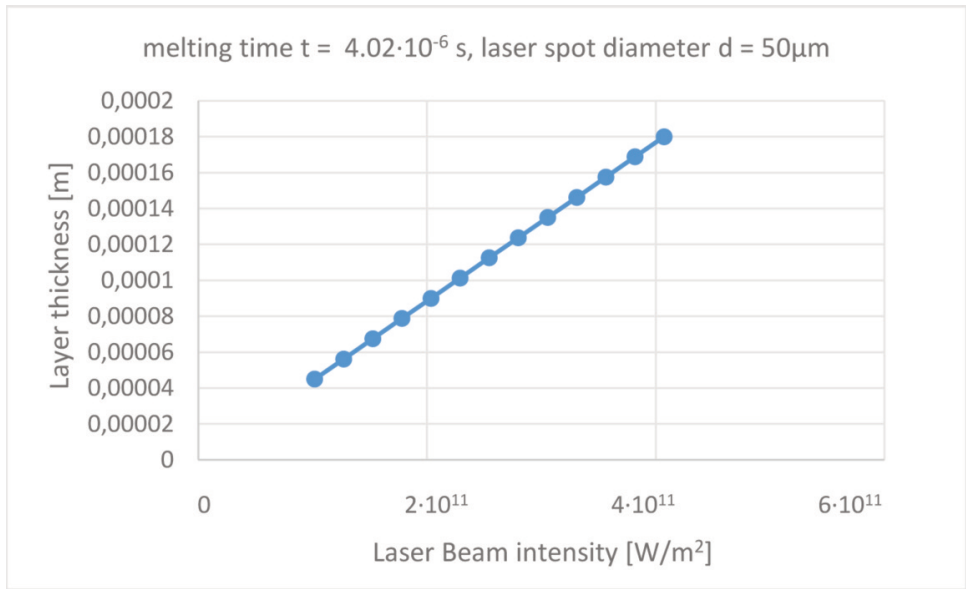

Fig. 7. Powder layer thickness vs laser beam intensity. 
Deeper molten thickness can be achieved using higher laser beam energy acting on powder bed. Calculation has been performed for laser power range from $P=200 \mathrm{~W}$ to $P=800 \mathrm{~W}$ for $h_{L}=25 \mu \mathrm{m}$, $h_{L}=35 \mu \mathrm{m}, h_{L}=50 \mu \mathrm{m}$ and $h_{L}=65 \mu \mathrm{m}$ of powder layer thickness. Assumed laser spot diameter $d=50 \mu \mathrm{m}$, both laser beam power and powder exposition area give power density from $q=1.02 \cdot 10^{11}$ to $4.07 \cdot 10^{11}\left[\mathrm{~W} / \mathrm{m}^{2}\right]$ (Fig. 8). Consider two different laser spot diameters for calculations $d=50 \mu \mathrm{m}$ and $d=300 \mu \mathrm{m}$ (Fig. 8).

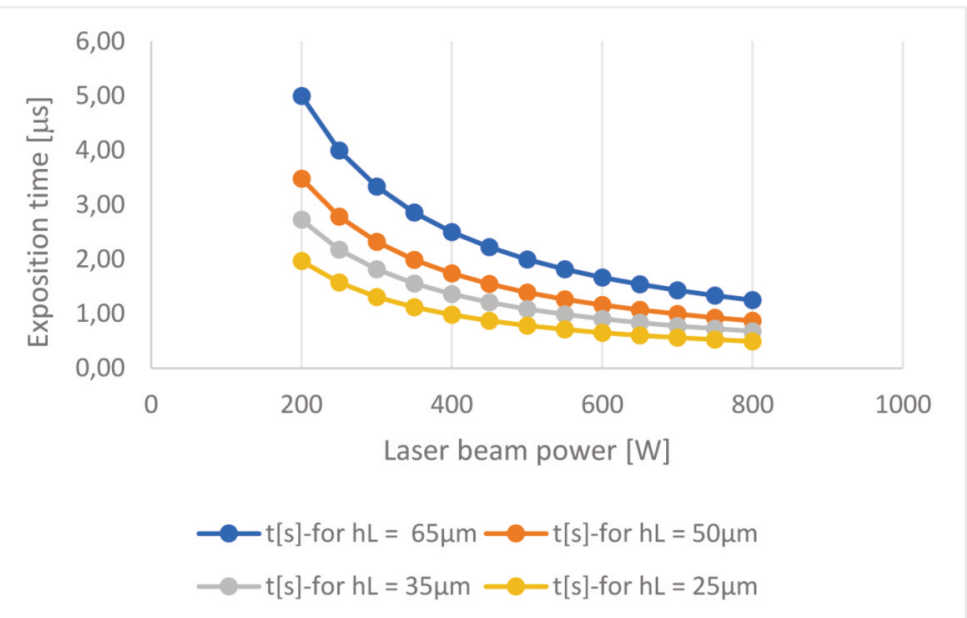

Fig. 8. Powder exposition time on laser beam vs laser beam power.

Laser spot diameter is $d=50 \mu \mathrm{m}$.

Time to start powder melting equation (23) strictly depends on laser energy density acting on powder layer. Using the same laser power to melt powder layer but smaller laser spot diameter results in higher speed of melting process. This can be explained that the energy density increases when the spot diameter decreases.

Performed analysis allows to determine which of the process parameters and material can be considered as most impacting on value of function being analyzed. Power of impact of particular parameters on layers thickness has also been calculated. Laser power $P=200 \mathrm{~W}$, laser spot diameter $d=50 \mu \mathrm{m}$, powder thermal conductivity coefficient $k_{e f}=7[\mathrm{~W} / \mathrm{mK}]$, powder porosity coefficient 0.15 , exposition time $t=4.02 \cdot 10^{-6} \mathrm{~s}$, powder energy absorption coefficient $\eta=0.16$ were used in analysis. Performed analysis have shown that the most impact on layer molten powder thickness has laser the spot diameter. Laser spot diameter change by $7.5 \%(3.75 \mu \mathrm{m})$ causes $15 \%$ change of molten powder thickness. Next parameter recognized as significant contributor is laser power.

$\Delta P=15[\mathrm{~W}]$ which is $7.5 \%$ of value used in analysis was assumed as increment of laser power. Calculated impact on layer thickness is $9.3 \%$ which means that changing laser power beam by $\Delta P=15 \mathrm{~W}$ results $\Delta h_{L}=4.3 \mu \mathrm{m}$ of layer thickness change. Powder exposition time on laser beam is also one of the parameters considered as a contributors impacting on layer thickness. $7.5 \%$ increase of exposition time makes $3.4 \mu$ increase of layer thickness which is $7.5 \%$ layer thickness change. For thermal conductivity coefficient, absorption and powder porosity insignificant impact has been observed. Parameters which are related to density of energy acting on powder are recognized as having bigger impact on molten powder layer thickness. $7.5 \%$ change of each parameter, cause the $31.8 \%$ thickness change.

Resultative error of part dimension, as a result of changes in thickness of layer sequences is very significant, therefore for further improvement of accuracy monitoring and control of SLS/SLM on-line processes is needed. 


\section{THE EFFECT OF SLM PARAMETERS ON SURFACE ROUGHNESS AND MATERIAL DENSITY}

Several studies have demonstrated that the part surface roughness and mechanical properties depend on the type of the AM technology, base material, laser type, layer thickness, build strategy, and postprocessing $[12,13]$.

\section{Surface roughness}

Surface roughness must be considered to assess product surface quality. The laser power $P$, scan speed $V$, hatching $P_{d}$ and powder bed thickness $h$ have been identified as the main factors that have an impact on the surface roughness $R a$.

The impact of material properties was considered in relation to the specific energy consumption $E_{c}$. The value of $E_{c}$ for the SLM process has been estimated by the energy required to melt a unit of volume. In other words the energy required to transform powder solid phase to liquid (Fig. 6), where the lower limit of this energy is equal to the melt enthalpy:

$$
E_{c}=\rho\left[c\left(T_{m}-T_{0}\right)+L_{m}\right]
$$

Therefore average surface roughness:

$$
R_{a}=f\left(P, V, P_{D}, H, h, E_{c}\right)
$$

Let us assume, that the mathematical model of the relation SLS/SLM conditions and average surface roughness $\mathrm{Ra}$ has been described by the power-law expression as following:

$$
R_{a}=P^{A} \cdot V^{B} \cdot P_{D}^{C} \cdot h^{D} \cdot E_{C}^{E}
$$

In these studies, the exponents in the Eq. 32 have been determined using the dimensional analysis.

\section{Dimensional Analysis}

In science and technology, measurements and parameters are used to describe a phenomenon or experiment. Those parameters are expressed as a number - a numerical quantity and a corresponding dimensional unit. One of the methods to formulate model is known as a dimensional analysis. This method uses physical quantities involved in experiment to build a model. Based on hypothesis saying that the problem solution can be expressed by means of a dimensionally homogenous equation. Dimensional analysis reduces the number of variables that must be specified to describe an event. This often leads to significant simplification. Buckingham $\pi$ theorem allows collecting all variables occurring in a problem into groups known as dimensionless $\pi$ terms [14]. Tab.1. contains physical parameters and their dimensional units used in Eq. 32. Semi empirical model based on Buckingham's $\pi$ theorem requires repeating variables use to satisfy dimensional homogeneity of the Eq. 32. Mass (M), length (L), time (T) are fundamental dimensions appeared in presented study.

In the case of Ra modeling, total number of variables $n=5$, fundamental dimensions $r=3$, so based on the Theorem of Buckingham $\pi$ will be $n-r=2$ i.e. two dimensionless $\pi$ terms, which are determined as follows:

$$
\operatorname{Dim}_{a}=\operatorname{Dim}\left(P^{A} \cdot V^{B} \cdot P_{D}^{C} \cdot h^{D} \cdot E_{C}^{E}\right)
$$


Physical parameters and dimensions are shown below:

$R a:$ L]

$P: \quad\left[\mathrm{ML}^{2} \mathrm{~T}^{-3}\right]$

$V:\left[\mathrm{LT}^{-1}\right]$

$P_{d}[\mathrm{~L}]$

h: [L]

$E_{c}:\left[\mathrm{ML}^{-1} \mathrm{~T}^{-2}\right]$

Substituting the above dimensions into eq. $(32,33)$ the system of equations determining the exponents takes the following form:
$L: 1=2 A+B+C+D-E$
T: $0=-3 A-B-2 E$
M: $0=A+E$

Hence

$D=-2 A-C+1$

$B=-A$

$E=-A$

After substitution of exponents (34-35) into eq. 32 the average surface roughness model $R a$ is expressed as:

$$
R_{a}=P^{A} \cdot V^{-A} \cdot P_{D}^{C} \cdot h^{-2 A-C+1} \cdot E_{C}^{-A}
$$

Dimensional analysis has been performed using Buckingham's $\pi$ theorem, each dimensionless $\pi$ terms are evaluated and shown below:

$$
\frac{R_{a}}{h}=\left(\frac{P}{V h^{2} E_{c}}\right)^{A} \cdot\left(\frac{P_{d}}{h}\right)^{C}
$$

Therefore:

$$
\frac{R_{a}}{h}=\pi_{1}^{A} \pi_{2}^{C}
$$

Where:

$$
\begin{aligned}
& \pi_{1}=\frac{P}{V h^{2} E_{c}} \\
& \pi_{2}=\frac{P_{d}}{h}
\end{aligned}
$$

The exponents $A$ and $C$ are determined experimentally.

\section{Experiments and model verification}

Experiment has been performed in New Manufacturing Technologies Department at Łukasiewicz Research Network - Institute of Aviation. Test samples were produced on 3D Printer SISMA MySint 100 using CoCr powder. Specimens geometry and main dimensions are shown on Fig. 9. 


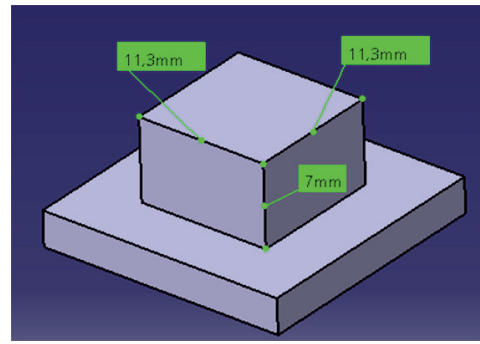

Fig. 9. Specimen geometry and main dimensions.

Quantity of specimens have been selected and based on Design of Experiment. Average surface roughness $\mathrm{Ra}$ was measured at three chosen locations on each wall surface, using a portable stylus type profilometer (Model: Surface Roughness Tester SJ-210). SLM process parameters used in the experiment are shown in Tab. 2.

Tab. 2. Process parameters.

\begin{tabular}{lcccc}
\hline Parameters & $\begin{array}{c}\text { Lower } \\
\text { limit }\end{array}$ & $\begin{array}{c}\text { Upper } \\
\text { limit }\end{array}$ & Unit & Dimension \\
\hline Laser Beam Power & 70 & 170 & $\mathrm{~W}$ & $\mathrm{ML}^{2} \mathrm{~T}^{-3}$ \\
Scanning Speed & 100 & 1200 & $\mathrm{~mm} / \mathrm{s}$ & $\mathrm{LT}^{-1}$ \\
$\begin{array}{l}\text { Hatching } \\
\begin{array}{l}\text { Powder Layer } \\
\text { thickness }\end{array}\end{array}$ & 45 & 105 & $\mu \mathrm{m}$ & $\mathrm{L}$ \\
\hline
\end{tabular}

Based on the performed experimental investigations, the value of exponents $A$ and $C$ have been determined. Those exponents values are as follows: $A=-0.078 ; C=-0.461$. After substituting these values into eq. 37 , the final equation of $\mathrm{Ra}$ is derived as follows:

$$
R_{a}=P^{-0.078} V^{0.078} E_{c}^{0.078} P_{d}^{-0.461} h^{1.62}
$$

Fig. 10 and Fig. 11 show plots of ratio Ra/h in function of $\pi_{1}, \pi_{2}$ terms.

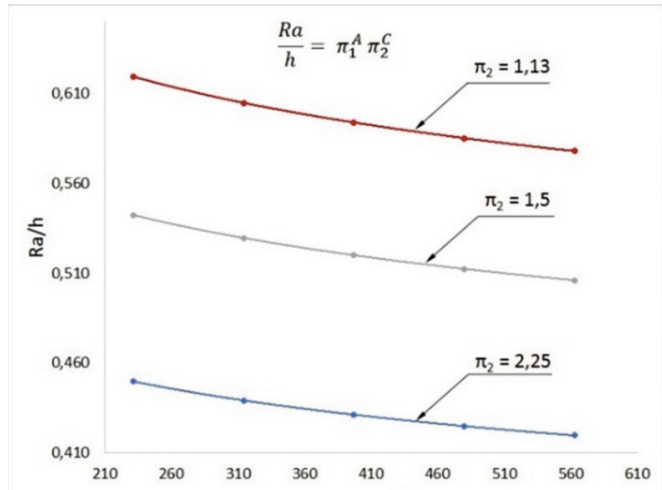

Fig. 10. Relation between $R a / h$ ratio and $\pi_{1}$ term at various $\pi_{2}$ term. 
Combination of process parameters (Laser beam power $P$, Scanning speed $V$, Powder layer thickness $h$ ) are represented by $\pi_{1}$ terms $(40)$ and were created for various powder layer thicknesses $(20 \mu \mathrm{m}, 30 \mu \mathrm{m}$, $40 \mu \mathrm{m})$, hatching $(45 \mu \mathrm{m})$. Similar plots for various $\pi_{1}$ terms are shown in Fig. 11.

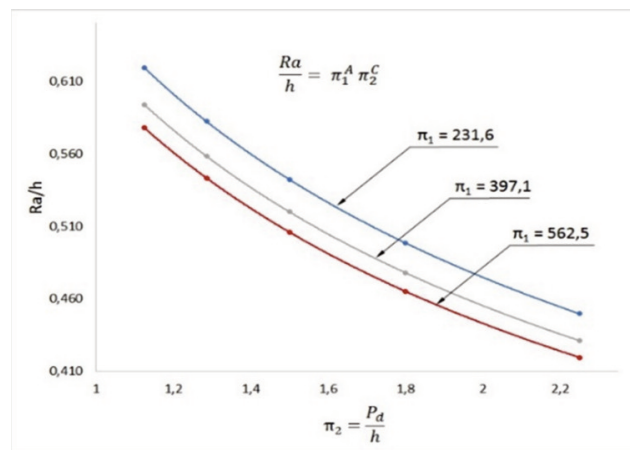

Fig. 11. Relation between Ralh ratio and $\pi_{2}$ term (various $\pi_{1}$ term).

Plots at various $\pi_{1}$ are built for different laser beam power levels $70 \mathrm{~W}, 120 \mathrm{~W}, 170 \mathrm{~W}$, scanning speed $V=100 \mathrm{~mm} / \mathrm{s}$ and powder layer thickness $h=20 \mu \mathrm{m}$. Additionally, it must be mentioned that specific energy consumption $E_{c}$ has been constant in these experiments.

Relations between SLM process parameters and samples average surface roughness are presented on plots: Fig. 12, Fig. 13, Fig. 14 and Fig. 15.

The Fig. 12 illustrates an effect of variable laser power $P$ on average surface roughness $R a$. Other process parameters $\left(V, P_{d}, h\right)$ controlled in this experiment remain unchanged, $V=650 \mathrm{~mm} / \mathrm{s}$, $P_{d}=75 \mu \mathrm{m}, h=30 \mu \mathrm{m}$.

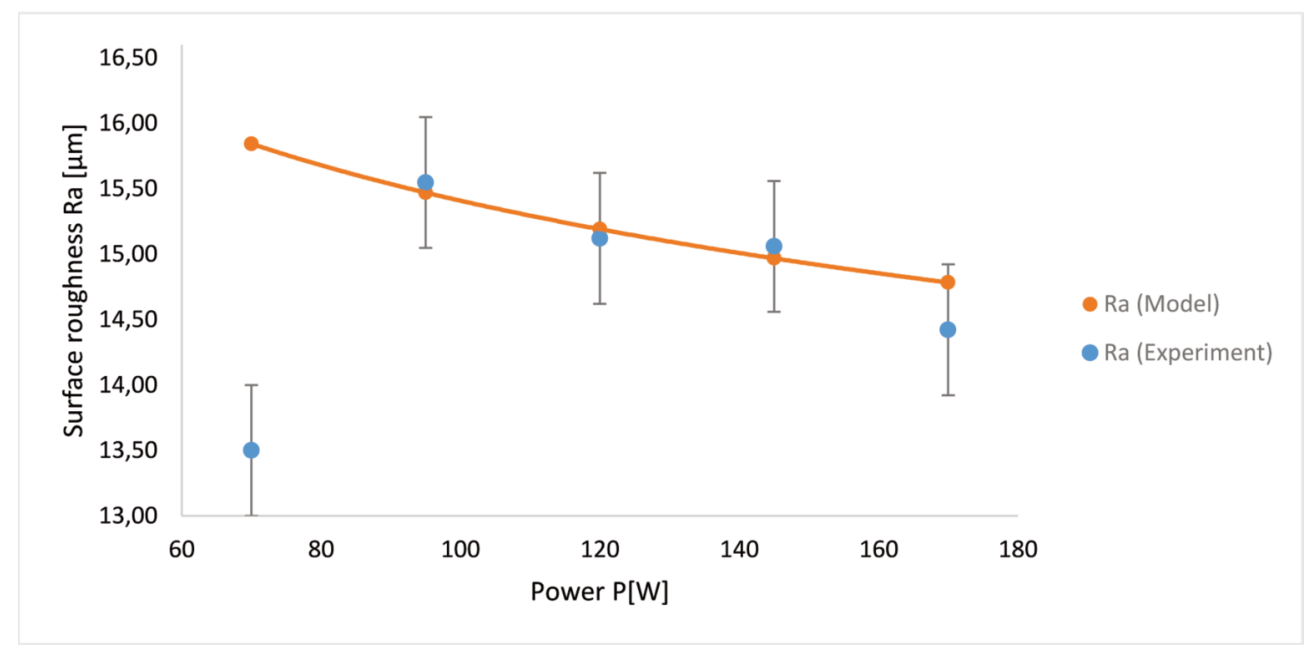

Fig. 12. Relation between $R a$ and laser beam power $P$ where $V=650 \mathrm{~mm} / \mathrm{s}, P_{d}=75 \mu \mathrm{m}, h=30 \mu \mathrm{m}$.

Fig. 12 shows average surface roughness improvement as result of laser power increase. It can be explained as more homogenous structure was built by re-melting previous built layers. Higher laser beam power allows to re-melt more of the previous built layers. 
Fig. 13 presents how scanning speed impacts on the average surface roughness. Increase of the scanning speed causes that an average surface roughness increases accordingly. This means that not enough energy (required to change powder solid phase to liquid phase) have been provided to powder during the AM process. Portion of the metal powder have not been molten during the process on laser track, causing the side wall surface imperfections.

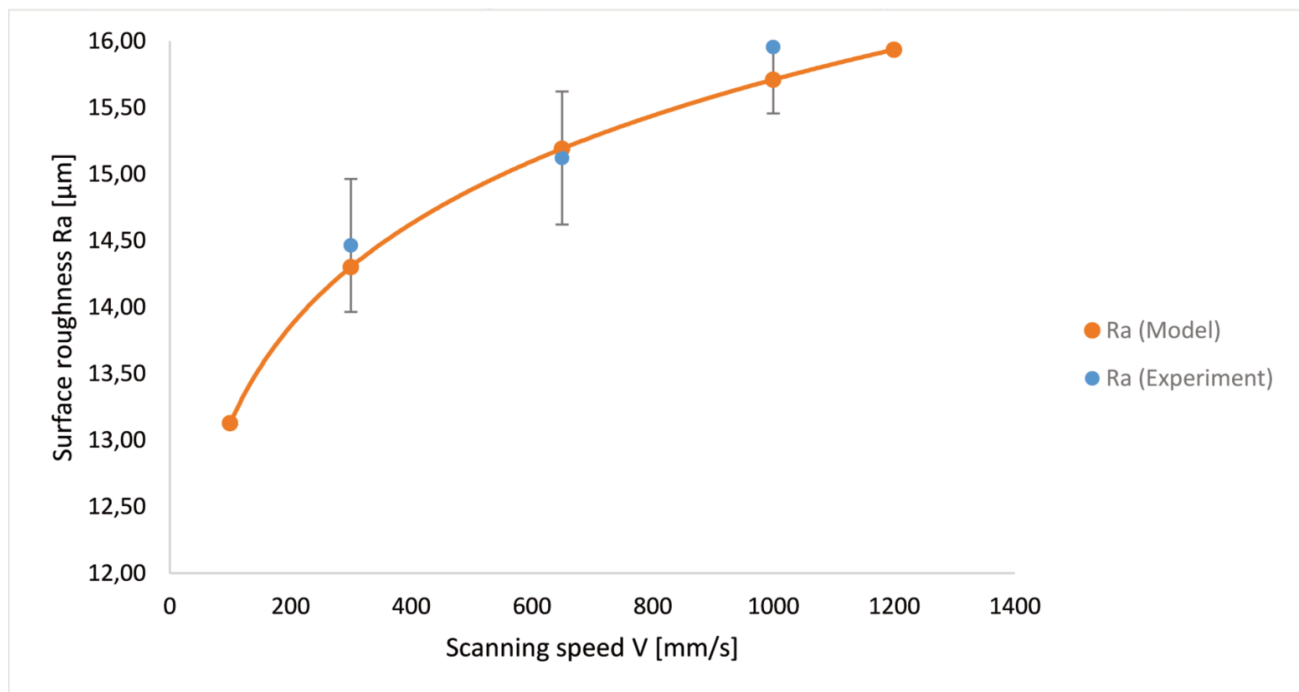

Fig. 13. Relation between $R a$ and laser scanning speed $V$ where $P=120 \mathrm{~W}, P_{d}=75 \mu \mathrm{m}, h=30 \mu \mathrm{m}$.

Both Fig. 12 and Fig. 13 confirm how important the balance of laser power $P$ and scanning speed $V$ setting is, in order to obtain the energy level required for proper powder melting. Proper balance of both those process parameters allows to effectively control the surface roughness. Hatching $P_{d}$ needs to be analyzed as one of the main factors next to laser power and scanning speed having impact on the surface roughness $R a$.

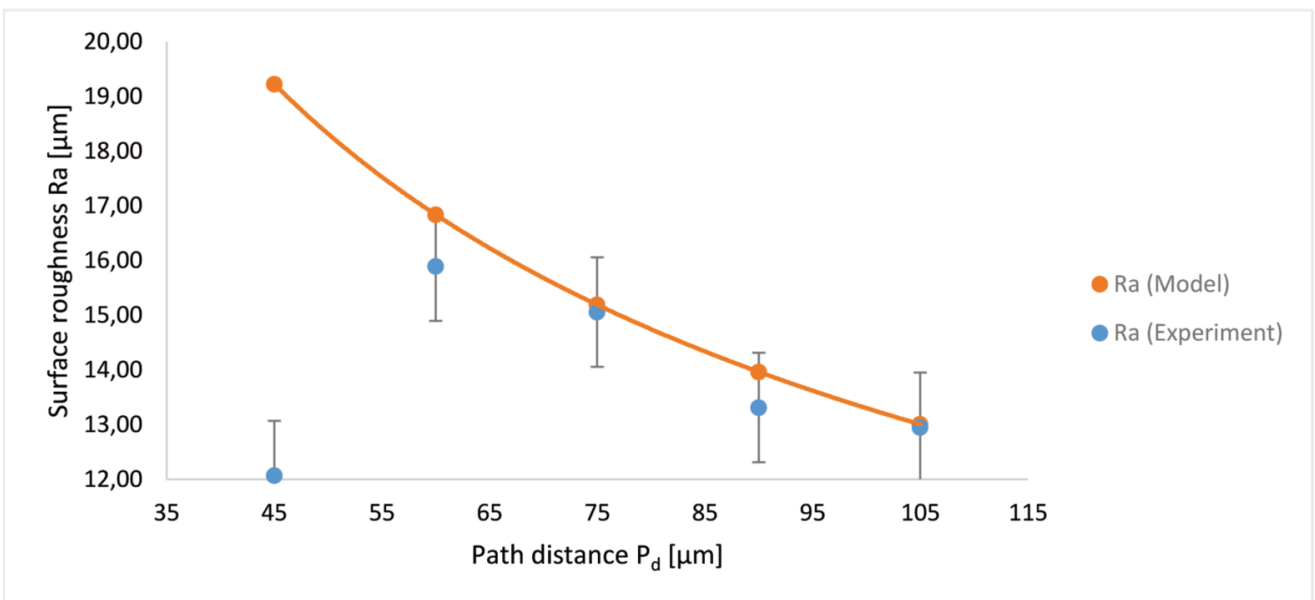

Fig. 14. Relation between $R a$ and hatching $P_{d}$ where $P=120 \mathrm{~W}, V=650 \mathrm{~mm} / \mathrm{s}, h=30 \mu \mathrm{m}$. 
The Fig. 14 indicates the impact of the hatching $P_{d}$ on wall surface roughness $R a$. Increasing the hatching $P_{d}$ results in the surface roughness Ra decrease for small powder layer thickness (similar to powder particle size of $30 \mu \mathrm{m}$ ). It must be highlighted, that powder layer thickness $h$ has the most significant impact on side wall roughness $\mathrm{Ra}$ as illustrated in Fig. 15. Therefore, producing a part using thinner powder layer, will effectively reduce the surface roughness. However, it takes more time to build parts with thin layers.

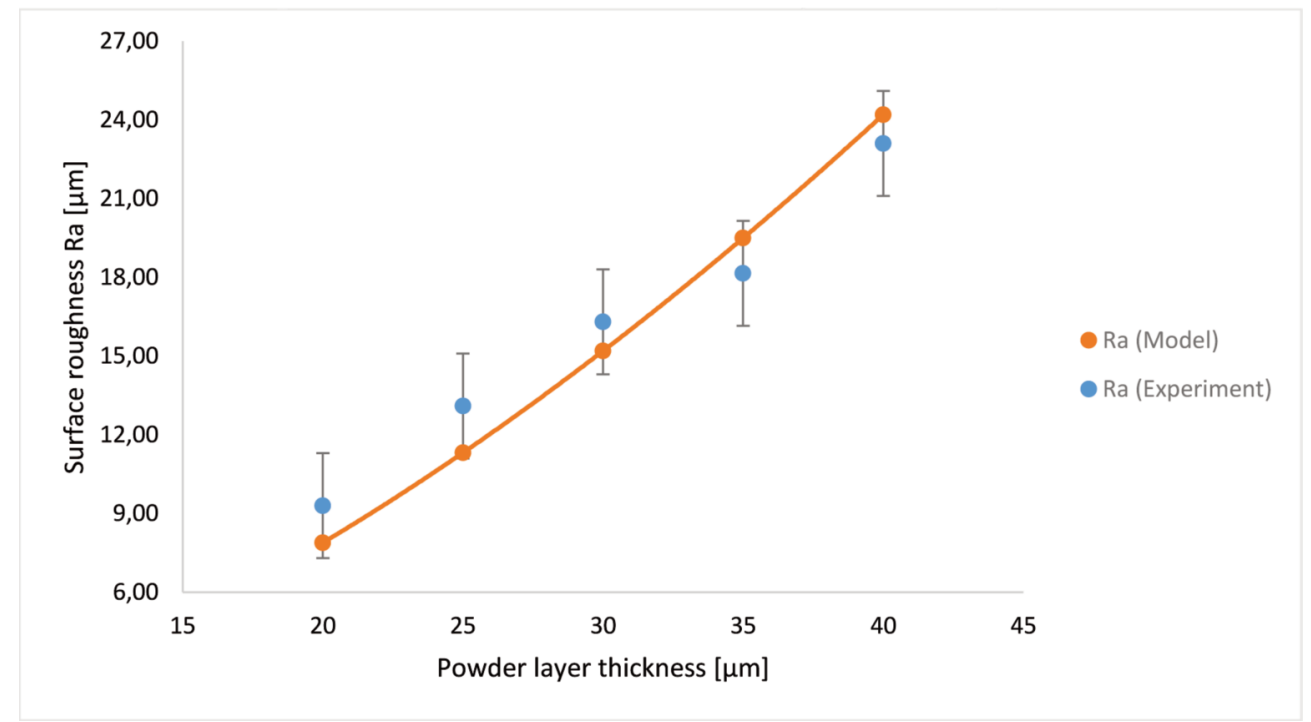

Fig. 15. Relation between $R a$ and powder layer thickness $h$ where $P=120 \mathrm{~W}, V=650 \mathrm{~mm} / \mathrm{s}, P_{d}=75 \mu \mathrm{m}$.

\section{Density Problem in SLS/SLM}

Controlling the porosity and thus the material density is one of the most important tasks to optimize the AM process, because porosity significantly reduces the mechanical properties of the final parts.

Proper energy density used during the manufacturing process guarantees low product porosity and high material density [11-13, 15].

Therefore, the most significant parameter of the SLM process affecting porosity is the volumetric energy density defined as follows:

$$
E_{\text {dens }}=\frac{P}{V h d}
$$

It has been found by several studies that by controlling the energy density in a specific range, the porosity in the final parts can be minimized [4]. When the energy density is insufficient, the inadequate melting will cause a large number of macroscopic pores, which significantly reduce the tensile strength and fatigue resistance of the final product.

Energy density $E_{\text {dens }}$ in this experiment was from $49 \mathrm{~J} / \mathrm{mm}^{3}$ to $727 \mathrm{~J} / \mathrm{mm}^{3}$. This range of $E_{\text {dens }}$ allows to obtain specimens density from $7,5 \mathrm{~g} / \mathrm{cm}^{3}$ to $8,6 \mathrm{~g} / \mathrm{cm}^{3}$. Where CoCr powder material density is equal $8,6 \mathrm{~g} / \mathrm{cm}^{3}$. It has been found that increasing the energy density $E_{\text {dens }}$ in the experiment leads to increase of the specimen's density. The relation between average material density of the built part and energy density has been shown in Fig. 16. 


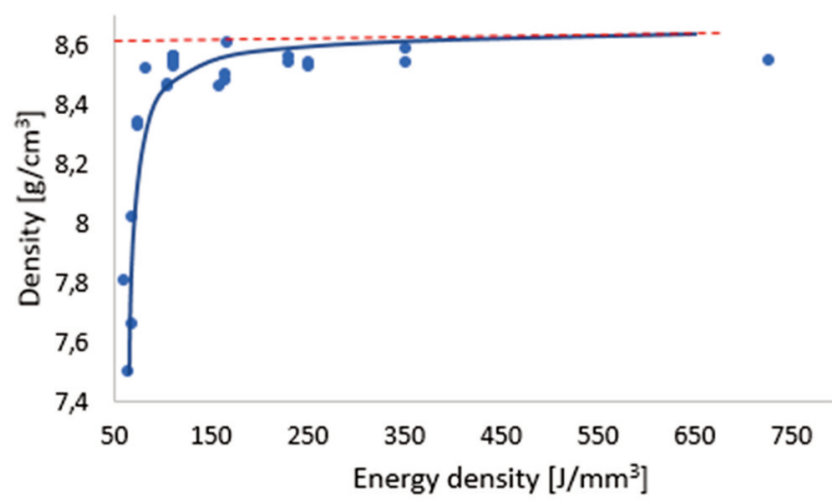

Fig. 16. Relation between the specimens density $\rho$ and energy density $E_{\text {dens }}$.

The high energy density will lead to metal boiling and vaporization. In addition, the intense inward Marangoni flow at high energy density results in gas bubble trapping and porosity increase [4]. Evidence of balling effect can be observed in Fig. 17 . Energy density $E_{\text {dens }}=727 \mathrm{~J} / \mathrm{mm}^{3}$ achieved in experiment shows numerous of balls appeared on the side wall surface.

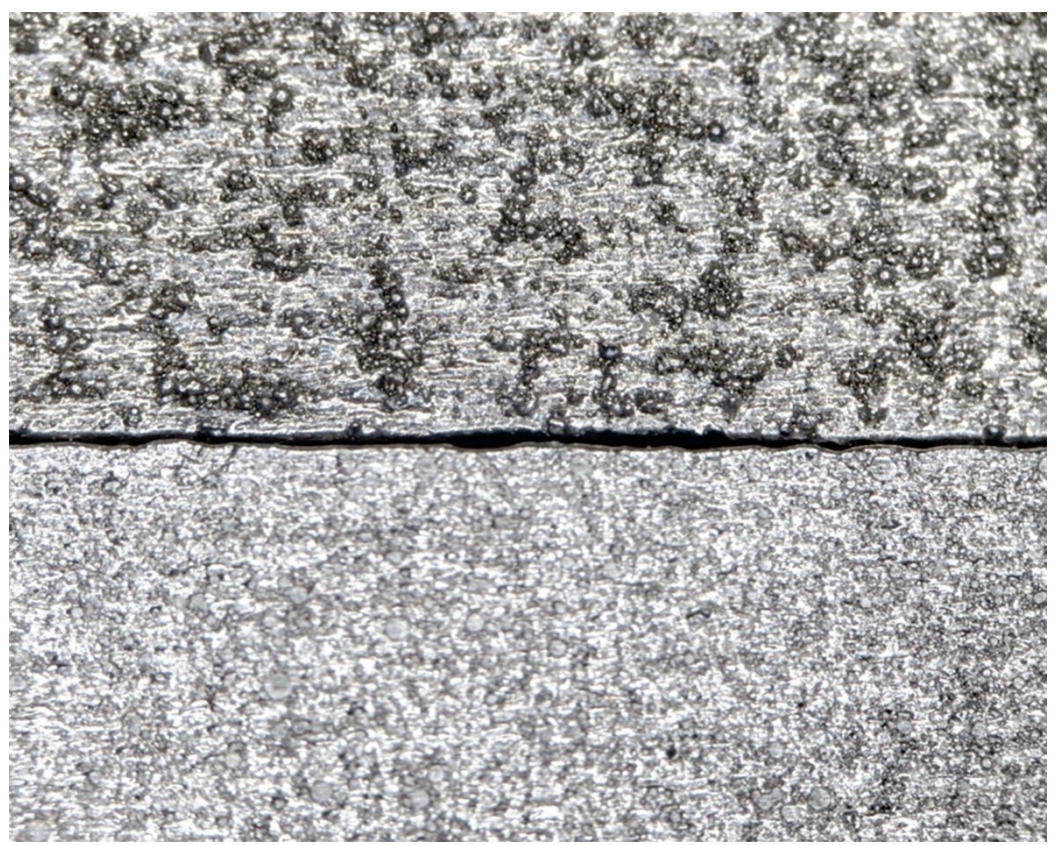

Fig. 17. Evidence of the balling effect was observed on sample No. $19\left(E_{\text {dens }}=727 \mathrm{~J} / \mathrm{mm}^{3}\right)$.

The top photo above shows a large number of balls on the side wall surface.

For comparison, the effect is not noticeable on sample No. $4\left(E_{\text {dens }}=105 \mathrm{~J} / \mathrm{mm}^{3}\right)$, where the printed surface is smooth.

Plots on Fig. 18 shows a strong correlation between surface roughness and porosity. Low porosity went with low surface roughness. 


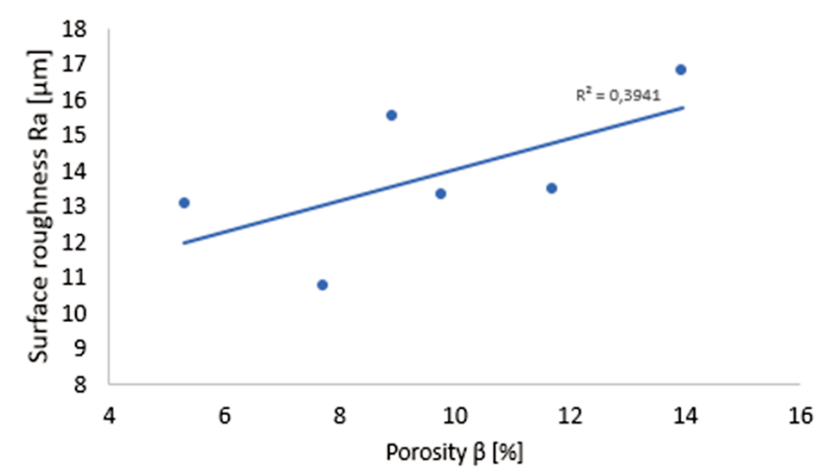

Fig. 18. Relation between porosity $\beta$ and surface roughness $R a$.

A relationship between the scan speed and laser power was noted, where the higher relative density was achieved at a low scan speed and high laser power. There must be mentioned that too high energy density drives to balling effect appearance. Balling effect observed on samples printed using energy density above $320 \mathrm{~J} / \mathrm{mm}^{3}$.

\section{SUMMARY AND RECOMMENDATION}

Sensitive analysis shows that the resultative error of part dimension as result of changes in thickness of layer sequences is very significant, therefore for further improvement of accuracy monitoring and control of SLS/SLM on-line processes is needed.

The mathematical model of the dependence of the average surface roughness $R a$ on the SLM parameters was successfully determined by means of dimensional analysis.

The surface roughness decreases as the distance between the scanning paths increases and the laser power increases. The mathematical model proved that the layer thickness has the greatest effect on the surface roughness and accuracy of the printed parts. A high laser power and a low powder layer thickness enable the production of samples with low porosity $(<1 \%)$. Increased powder layer thickness leads to rapid increase in porosity level and surface roughness. Setting a low powder thickness value effectively improves the quality of the print surface, but clearly extends the duration of the print.

The optimum range of energy density is $112-168 \mathrm{~J} / \mathrm{mm}^{3}$ based on experiment, which results in relative density from $99.5 \%$ to $99.9 \%$. The lowest porosity was achieved with $120 \mathrm{~W}$ and $650 \mathrm{~mm} / \mathrm{s}$. Moreover high density of $99.4 \%$ observed on sample printed with energy density of $720 \mathrm{~J} / \mathrm{mm}^{3}$, however balling effect was noticed on this sample. This effect appeared for scan speed $100 \mathrm{~mm} / \mathrm{s}$ and laser power $120 \mathrm{~W}$.

\section{REFERENCES}

[1] Gibson, L., Rosen, D. and Stucker, B., 2009, Additive manufacturing technologies: rapid prototyping to direct digital manufacturing, Springer New York Heidelberg Dordrecht London.

[2] EPMA, 2019, Introduction to Additive Manufacturing Technology, third edition, European Powder Metallurgy Association. https:/www.epma.com/epma-free-publications/product/introduction-toadditive-manufacturing-brochure.

[3] Meier, Ch., Penny, R., Zou, Y., Gibbs J. S. and Hart, A. J., 2014, “Thermophysical Phenomena in Metal Additive Manufacturing by Selective Laser Melting: Fundamentals, Modeling, Simulation and Experimentation", Annual Review of Heat Transfer, 20, pp. 241-316.

10.1615/AnnualRevHeatTransfer.2018019042. 
[4] Yadroitsau, I., 2008, "Fabrication directe d'objets 3D par fusion sélective laser à partir des poudres métalliques". PhD thesis, Université Jean-Monnet.

[5] Kozak, J., 2018, Mathematical Modelling of Advanced Manufacturing Processes. Institute of Aviation Scientific Publications Division, ISBN: 978-83-63539-49-8, Warsaw, Poland.

[6] https://www.google.pl/search?q=ge+3d+printed+jet+engine\&client=opera\&biw=1240\&bih=610\&t b $m=$ isch $\&$ tbo $=$ u $\&$ source $=$ univ $\&$ sa $=X \& v e d=0$ ahUKEwiAycD_1 snbAhXmdpoKHdPgCFMQsAQIIQE.

[7] Kozak, J. and Zakrzewski T., 2018, "Accuracy problems of additive manufacturing using SLS/SLM processes", AIP Conference Proceedings.

[8] Carslow, H. S. and Jaeger, J. C., 1959, Conduction of Heat in Solids, Oxford University Press, Oxford, UK.

[9] Alexiades, V. and Solomon, A. D., 1993, Mathematical Modeling of Melting and Freezing Processes, Washington: Hemisphere Publishing Corporation.

[10] Cohen, M.I. and Epperson, J.P., 1968, "Application of Lasers to Microelectronic Fabrication", Advances in Electronics and Electron Physics, pp. 139-186.

[11] Bossak, M., and Kozak, J., 2003, "Selected problems of Designing and Manufacturing MEMSAccelerometers". Proceed. Of Symposium on Novel Vehicle Concepts and Emerging Vehicle Technologies, Brussels.

[12] Egger, G., Gygax, P.-E., Glardon, R. and Karapatis, N. P., 1999, "Optimization of powder layer density in selective laser sintering”. 10th Solid Freeform Fabrication Proceedings, pp. 255-263.

[13] Ahmed H. Maamoun, Yi F. Xue, Mohamed A. Elbestawi, Stephen C. Veldhuis, 2018, "Effect of Selective Laser Melting Process Parameters on the Quality of Al Alloy Parts: Powder Characterization, Density, Surface Roughness, and Dimensional Accuracy”, Materials, 11(12), p. 2343.

$10.3390 / \mathrm{mal} 1122343$.

[14] Gibbings, J.C., 2011, Dimensional Analysis, Springer, London.

[15] Chunlei Qiu, Chinnapat Panwisawas, Mark Ward, Hector C. Basoalto, Jeffery W. Brooks, Moataz M. Attallah, 2015, "On the role of melt flow into the surface structure and porosity development during selective laser melting", Acta Materialia, 96, pp. 72-79.

[16] Sola, A. and Nouri, A., 2019, "Microstructural porosity in additive manufacturing: The formation and detection of pores in metal parts fabricated by powder bed fusion", Journal of Advanced Manufacturing and Processing, 1(3). 10.1002/amp2.10021.

\title{
WYBRANE ZAGADNIENIA TECHNOLOGII PRZYROSTOWEJ Z ZASTOSOWANIEM PROCESÓW SLS/SLM
}

\begin{abstract}
Abstrakt
W pracy przedstawiono kluczowe problemy związane z wdrożeniem technologii przyrostowej druku 3D w metalu, w szczególności wybór i optymalizację parametrów procesu. W pierwszej sekcji omówiono zagadnienia dokładności, druga porusza temat jakości powierzchni i problem porowatości/ gęstości przetopionego materiału określające właściwości mechaniczne wytwarzanych produktów.

Technologia przyrostowa (AM) oparta na selektywnym spiekaniu laserowym (SLS) i selektywnym topieniu laserowym (SLM) jest coraz szerzej stosowana do wytwarzania części o skomplikowanych kształtach. Mimo wielu zalet procesu SLM w porównaniu z konwencjonalną obróbką, głównymi wadami są stosunkowo niska jakość powierzchni i występowanie porowatości/niskiej gęstości przetopionego materiału. Badania doświadczalne przeprowadzone zostały w Zakładzie Nowoczesnych Technik
\end{abstract}


Wytwarzania w Sieci Badawczej Łukasiewicz - Instytucie Lotnictwa. Próbki testowe wytworzono na drukarce 3D SISMA MySint 100 przy użyciu proszku CoCr. W badaniach na podstawie analizy wymiarowej sformułowano model matematyczny opisujący zależność średniej chropowatości powierzchni Ra od parametrów procesu SLM. Pomiary geometrii próbek na współrzędnej maszynie pomiarowej CMM i profilometrze wykorzystującym przewodność indukcyjną "Surftest SJ-210" potwierdziły adekwatność modelu matematycznego, a w szczególności, że chropowatość maleje wraz ze wzrostem mocy lasera oraz ze wzrostem odległości między ścieżkami skanowania, natomiast rośnie wraz z grubością proszku i prędkością skanowania. Zwiększenie mocy lasera i zmniejszenie grubości warstwy proszku umożliwia wytwarzanie próbek o porowatości poniżej 1\%. Zwiększona grubość warstwy proszku prowadzi do szybkiego wzrostu poziomu porowatości i chropowatości powierzchni. Ustawienie niskiej warstwy skutecznie poprawia jakość powierzchni wydruku, ale wyraźnie wydłuża czas drukowania.

Słowa kluczowe: technologia przyrostowa, SLM, analiza wymiarowa. 